\title{
Spontaneous, L-Arginine-Induced and Spironolactone- Induced Regression of Protein Remodeling of the Left Ventricle in L-NAME-Induced Hypertension
}

\author{
F. ŠIMKO ${ }^{1,2}$, A. POTÁČOVÁ ${ }^{3}$, V. PELOUCH ${ }^{4}$, L'. PAULIS ${ }^{1,5}$, J. MATÚŠKOVÁ ${ }^{1}$, \\ K. KRAJČÍROVIČOVÁ ${ }^{1}$, O. PECHÁŇOVÁ ${ }^{5,6}$, M. ADAMCOVÁ ${ }^{3}$ \\ ${ }^{1}$ Department of Pathophysiology, ${ }^{2}$ Third Clinic of Medicine, School of Medicine, Comenius \\ University, Bratislava, Slovak Republic, ${ }^{3}$ Department of Physiology, Faculty of Medicine, Charles \\ University, Hradec Králové, Czech Republic, ${ }^{4}$ Department of Medical Chemistry and Biochemistry, \\ Second Faculty of Medicine and Centre for Cardiovascular Research, Charles University, Prague, \\ Czech Republic, ${ }^{5}$ Institute of Normal and Pathological Physiology, Slovak Academy of Sciences, \\ Bratislava, Slovak Republic, ${ }^{6}$ Institute of Physiology, Academy of Sciences of the Czech Republic, \\ Prague, Czech Republic \\ Received July 4, 2007 \\ Accepted August 28, 2007 \\ On-line available September 5, 2007
}

\begin{abstract}
Summary
$\mathrm{N}^{\mathrm{G}}$-nitro-L-arginine-methyl ester (L-NAME)-induced hypertension is associated with protein remodeling of the left ventricle. The aim of the study was to show, whether aldosterone receptor blocker spironolactone and precursor of NOproduction L-arginine were able to reverse the protein rebuilding of the left ventricle. Six groups of male Wistar rats were investigated: control 4 (4 weeks placebo), L-NAME (4 weeks L-NAME), spontaneous-regression (4 weeks L-NAME +3 weeks placebo), spironolactone-regression (4 weeks L-NAME +3 weeks spironolactone), L-arginineregression (4 weeks L-NAME +3 weeks arginine), control 7 (7 weeks placebo). L-NAME administration induced hypertension, hypertrophy of the left ventricle (LV), and the increase of metabolic and contractile as well as soluble and insoluble collagenous protein concentration. The systolic blood pressure and relative weight of the LV decreased in all three groups with regression, while the most prominent attenuation of the LVH was observed after spironolactone treatment. In the spontaneous-regression and L-arginine-regression groups the concentrations of individual proteins were not significantly different from the control value. However, in the spironolactone-regression group the concentration of metabolic, contractile and insoluble collagenous proteins remained significantly increased in comparison with the control group. The persistence of the increased protein concentration in the spironolactone group may be related to the more prominent reduction of myocardial water content by spironolactone.
\end{abstract}

Key words

Collagen $\bullet$ L-NAME hypertension $\bullet$ L-arginine $\bullet$ Spironolactone $\bullet$ Regression of hypertrophy 


\section{Introduction}

Left ventricular hypertrophy (LVH), although an adaptive mechanism compensating increased hemodynamic overload, is an independent risk factor of increased cardiovascular morbidity and mortality through higher incidence of heart failure, arrhythmias, myocardial infarction or stroke. It is believed that regression of $\mathrm{LVH}$ diminishes the level of cardiovascular risk (Devereux et al. 2004).

A number of drugs are being tested to determine their potential to reverse LVH (Mandarim-de-Lacerda and Pereira 2003, Klingbeil et al. 2003, Kojšová et al. 2006, Šimko and Paulis 2007). Nitric oxide was shown to have not only vasodilator but also antiproliferative and antihypertrophic properties (Kolpakov et al. 1995, Šimko and Šimko 2000, Šimko 2007a,b). The substrate for NO formation L-arginine was shown to reduce blood pressure in humans (Nakaki et al. 1990) and to reverse LVH in spontaneously hypertensive rats (Matsuoka et al. 1996), however it failed to prevent hypertension and LVH in L-NAME-induced hypertension (Šimko et al. 2005). Aldosterone is the growth stimulating factor, participating in the LVH and fibrosis development (Brilla et al. 1993). Spironolactone, the blocker of aldosterone receptor, reduced the extent of LVH and DNA concentration in L-NAME-induced hypertension in a preventive experiment (Šimko et al. 2007). Most importantly, spironolactone reduced mortality in patients with severe heart failure in the Randomised Aldactone Evaluation Study (RALES) when added to standard treatment (Pitt et al. 1999, Šimko et al. 2002), while antifibrotic potential of spironolactone was considered to play an important role in this benefit (Zannad et al. 2000).

In previous experiments, L-NAME was shown to induce hypertension, hypertrophy and fibrosis of the left ventricle (Pecháňová et al. 1997, Šimko et al. 2007). The aim of this study was to show whether L-arginine and spironolactone are able to reverse the collagenous and non-collagenous protein remodeling of the $\mathrm{LV}$ in NO-deficient hypertension.

\section{Methods}

\section{Animals and treatment}

Male 12-week-old Wistar rats were randomly divided into six groups. In the control $4(\mathrm{CT} 4, \mathrm{n}=8)$ group the animals were sacrificed after 4-week placebo treatment and in the control $7(\mathrm{CT} 7, \mathrm{n}=8)$ group after

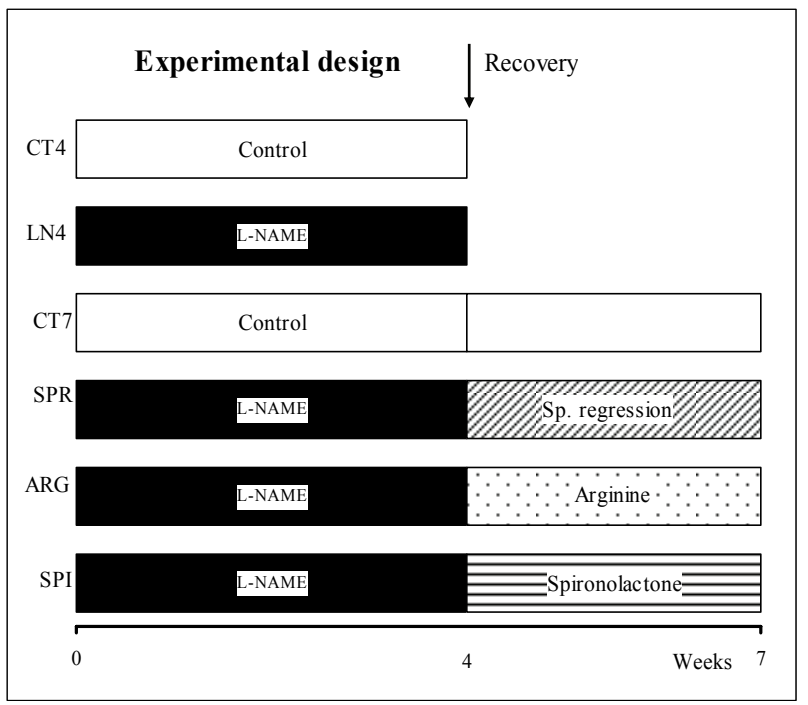

Fig. 1. Experimental design. CT4 and CT7, controls; LN4, 4-week $40 \mathrm{mg} / \mathrm{kg} /$ day L-NAME; SPR, 4-week L-NAME + 3-week placebo; ARG, 4-week L-NAME + 3-week $1500 \mathrm{mg} / \mathrm{kg} /$ day L-arginine; SPI, 4-week L-NAME + 3-week 200 mg/kg/day spironolactone.

7-week placebo treatment. The L-NAME group (LN4, $\mathrm{n}=9$ ), where $40 \mathrm{mg} / \mathrm{kg}$ /day L-NAME was given for 4 weeks, served for assessment of the development of L-NAME-induced alterations and was compared with CT4. In the residual three groups the regression of L-NAME-induced alterations was observed and was compared with the both LN4 and CT7 groups. In these groups the 4-week L-NAME-treatment (40 mg/kg/day) was replaced by 3 weeks of either placebo treatment in the spontaneous recovery group $(\mathrm{SPR}, \mathrm{n}=9)$ or by administration of $1500 \mathrm{mg} / \mathrm{kg}$ /day L-arginine (Merck, Germany) in the L-arginine-induced recovery group (ARG, $\mathrm{n}=9$ ), or by administration of $200 \mathrm{mg} / \mathrm{kg} /$ day spironolactone (Gedeon, Hungary) in the spironolactoneinduced recovery group (SPI, n=9). Experimental design is given in Figure 1.

All animals were housed in individual cages at a temperature of $22-24{ }^{\circ} \mathrm{C}$ and fed a regular pellet diet, with access to food and water ad libitum. L-NAME and L-arginine were given in tap water and spironolactone was mixed with methylcellulose as an emulsion and was applied via gavage twice daily. Moreover, all other animals were gavaged with placebo (methylcellulose) twice daily so that handling conditions were preserved for all animals in the experiment. The investigation conformed to the Guide for the Care and Use of Laboratory Animals published by the US National Institutes of Health (NIH Publication No. 8532, revised 1985). 


\section{Hemodynamic parameters}

The systolic blood pressure (SBP) was measured weekly by non-invasive tail-cuff plethysmography (Hugo-Sachs Elektronik KG, Germany). After 6 weeks the rats were sacrificed by decapitation and the heart was excised. The body weight (BW), left ventricle weight (LVW) and right ventricle weight (RVW) were determined and $\mathrm{RVW} / \mathrm{BW}$ as well as $\mathrm{LVW} / \mathrm{BW}$ ratios were calculated.

\section{Determination of left ventricle protein profile}

The LV samples were rapidly weighed and transferred into precooled homogenization test tubes. They were frozen subsequently to $-50{ }^{\circ} \mathrm{C}$. Tissue samples were later thawed, a 40-fold volume was achieved by adding $50 \mathrm{mmol} / 1$ sodium-potassium phosphate buffer, pH 7.4 containing $10 \mathrm{mmol} / 1$ EDTA and $1 \%$ Triton $\mathrm{X}$, homogenized and centrifuged at $15000 \mathrm{x}$ g; supernatant was used for the determination of metabolic proteins (MP). The pellet was resuspended and fractions of contractile and collagenous proteins were obtained in a stepwise manner by extracting contractile proteins into a supernatant with phosphate buffer (100 mmol/1, pH 7.7, containing $1.1 \mathrm{mmol} / \mathrm{K} \mathrm{KCl})$. The pellet was shortly washed with $0.5 \mathrm{~mol} / 1$ acetic acid then extracted with $0.5 \mathrm{~mol} / 1 \mathrm{CH}_{3} \mathrm{COOH}$-pepsin concentration was kept in the range $1: 100-1: 50$. After $24 \mathrm{~h}$ at $4{ }^{\circ} \mathrm{C}$, the extracts were centrifuged. The supernatant contained the fraction of soluble collagenous proteins. The pellet was further suspended in $1.1 \mathrm{~mol} / 1 \mathrm{NaOH}$ and left for $45 \mathrm{~min}$ at $105^{\circ} \mathrm{C}$. This fraction contained insoluble collagenous proteins. The protein profile procedure yielded three basic fractions: 1) metabolic proteins (containing predominantly enzyme systems for aerobic and anaerobic substrate utilization) (Bass et al. 1988); 2) contractile proteins (complex of contractile, regulatory and modulatory proteins of myofibrils); 3) structural collagenous proteins (the fraction included collagens, elastins, proteoglycans and glycoproteins), which can be divided into two fractions: (a) soluble collagenous proteins constituted mainly by collagen I and III and (b) insoluble collagenous proteins including collagen aggregates, elastins and other proteins of the extracellular matrix. This methodological approach has been described in detail elsewhere (Pelouch et al. 1993, 1995, 1996). Protein concentration in individual fractions was determined according to Lowry et al. (1951) and expressed per g of tissue wet weight; protein content was expressed per total LV wet weight.
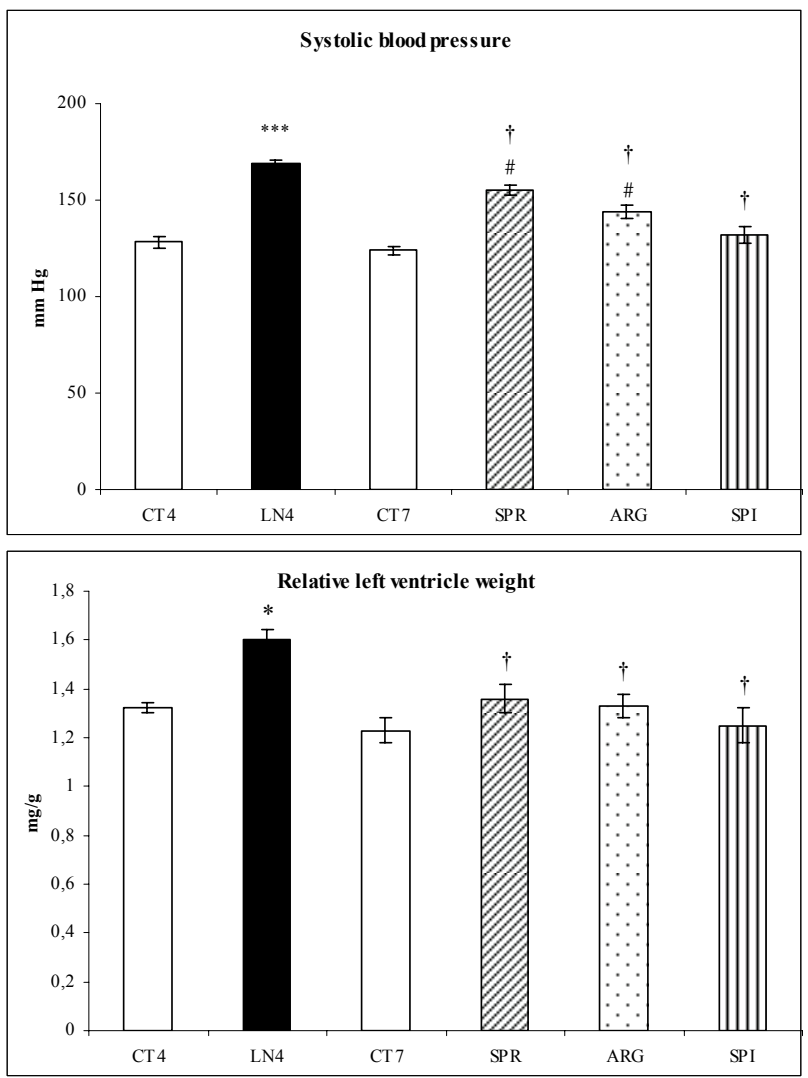

Fig. 2. Left ventricle weight and the systolic blood pressure (SBP). CT4 and CT7, controls; LN4, 4-week L-NAME; SPR, 4week L-NAME + 3-week placebo; ARG, 4-week L-NAME + 3-week L-arginine; SPI, 4-week L-NAME + 3-week spironolactone. *** $\mathrm{P}<0.001$ vs. CT4; ${ }^{*} \mathrm{P}<0.05$ vs. CT7; ${ }^{\dagger} \mathrm{P}<0.05$ vs. LN4.

\section{Statistical analysis}

Values of individual parameters expressed in figures and tables are declared as mean \pm SEM. Statistical evaluation was performed using the SigmaStat software program (revision STAT 32 2.0, Jandel GmbH, Erkrath, Germany).

\section{Results}

\section{Blood pressure and weight of the heart}

After four weeks of experiment, the SBP was $128 \pm 3 \mathrm{~mm} \mathrm{Hg}$ in the CT4 group. L-NAME administration elevated SBP by $32 \%(\mathrm{P}<0.001)$ vs. CT4 group. After seven weeks, the SBP was $124 \pm 2 \mathrm{~mm} \mathrm{Hg}$ in the CT7 group. In all recovery groups SBP decreased significantly $(\mathrm{P}<0.05)$ compared to the LN4 group, however, compared to CT7 group, SBP remained elevated $(\mathrm{P}<0.05)$ in the $\mathrm{SPR}$ and $\mathrm{ARG}$ group, respectively (Fig. 2).

After four weeks, the $\mathrm{LVW} / \mathrm{BW}$ ratio was $1.32 \pm 0.02 \mathrm{mg} / \mathrm{g}$ in CT4 group. In LN4 group the $\mathrm{LVW} / \mathrm{BW}$ ratio increased by $21 \%(\mathrm{P}<0.05)$ vs. CT4 
Table 1. The effect of L-NAME-induced hypertension and its regression on body weight (BW), left ventricle weight (LVW), right ventricle weight (RVW) and relative right ventricle weight (RVW/BW).

\begin{tabular}{lcccc}
\hline BW & $\mathbf{( g )}$ & $\begin{array}{c}\mathbf{L V W} \\
\mathbf{( m g )}\end{array}$ & $\begin{array}{c}\mathbf{R V W} \\
\mathbf{( m g})\end{array}$ & $\begin{array}{c}\mathbf{R V W} / \mathbf{B W} \\
(\mathbf{m g} / \mathbf{g})\end{array}$ \\
\hline \multirow{2}{*}{ CT4 } & $376 \pm 7$ & $497.1 \pm 12.2$ & $158.3 \pm 4.7$ & $0.42 \pm 0.02$ \\
$L N 4$ & $333 \pm 8^{*}$ & $530.4 \pm 13.8$ & $143.7 \pm 7.8$ & $0.43 \pm 0.02$ \\
$C T 7$ & $403 \pm 6$ & $495.6 \pm 17.5$ & $181.0 \pm 10$ & $0.45 \pm 0.02$ \\
$S P R$ & $373 \pm 8 \boldsymbol{\dagger}$ & $505.8 \pm 19.6$ & $189.2 \pm 9.3 \dagger$ & $0.51 \pm 0.03$ \\
$A R G$ & $368 \pm 8$ & $485.6 \pm 14.5$ & $182.6 \pm 9.0 \dagger$ & $0.50 \pm 0.03$ \\
$S P I$ & $362 \pm 11 \#$ & $446.4 \pm 18.6 \dagger$ & $161.1 \pm 5.7$ & $0.45 \pm 0.02$ \\
\hline
\end{tabular}

CT4 and CT7, controls; LN4, 4-week L-NAME; SPR, 4-week L-NAME + 3-week placebo; ARG, 4-week L-NAME + 3-week L-arginine; SPI, 4-week L-NAME + 3-week spironolactone. * $\mathrm{P}<0.05$ vs. CT4; \# $\mathrm{P}<0.05$ vs. CT7; + $\mathrm{P}<0.05$ vs. LN4

Table 2. Content (mg) of individual proteins.

\begin{tabular}{|c|c|c|c|c|}
\hline & \multicolumn{4}{|c|}{ Content (mg) } \\
\hline & $\begin{array}{c}\text { metabolic } \\
\text { proteins }\end{array}$ & $\begin{array}{c}\text { contractile } \\
\text { proteins }\end{array}$ & $\begin{array}{c}\text { soluble collagenous } \\
\text { proteins }\end{array}$ & $\begin{array}{c}\text { insoluble } \\
\text { collagenous proteins }\end{array}$ \\
\hline CT4 & $41.09 \pm 1.02$ & $44.10 \pm 0.77$ & $22.30 \pm 0.082$ & $5.89 \pm 0.60$ \\
\hline LN4 & $50.09 \pm 2.28 *$ & $52.03 \pm 2.02 *$ & $27.57 \pm 1.08 *$ & $9.63 \pm 0.95 *$ \\
\hline$C T 7$ & $41.87 \pm 1.47$ & $44.04 \pm 1.41$ & $22.83 \pm 1.27$ & $6.17 \pm 0.56$ \\
\hline$S P R$ & $45.94 \pm 2.28$ & $49.94 \pm 2.16$ & $24.65 \pm 0.92$ & $7.18 \pm 0.56$ \\
\hline$A R G$ & $43.02 \pm 1.74$ & $46.71 \pm 1.87$ & $22.54 \pm 0.70 \dagger$ & $5.99 \pm 0.29 \dagger$ \\
\hline$S P I$ & $39.44 \pm 1.98+$ & $42.23 \pm 2.41 \dagger$ & $19.50 \pm 0.56 \dagger$ & $6.03 \pm 0.70 \dagger$ \\
\hline
\end{tabular}

CT4 and CT7, controls; LN4, 4-week L-NAME; SPR, 4-week L-NAME + 3-week placebo; ARG, 4-week L-NAME + 3-week L-arginine; SPI, 4-week L-NAME + 3-week spironolactone. $* \mathrm{P}<0.05$ vs. CT4; $+\mathrm{P}<0.05$ vs. LN4

group. LVW/BW decreased significantly $(\mathrm{P}<0.05)$ in all groups with regression (SPR, ARG, SPI) vs. LN4 (Fig. 2, Table 1).

\section{Protein composition of the left ventricle}

In the LN4 group, the concentration of metabolic proteins $(94.39 \pm 3.74 \mathrm{mg} / \mathrm{g})$ increased significantly $(\mathrm{P}<0.05)$ vs CT4 $(82.69 \pm 1.71 \mathrm{mg} / \mathrm{g})$. The concentration of contractile proteins $(97.88 \pm 2.90 \mathrm{mg} / \mathrm{g})$ was higher $(\mathrm{P}<0.05)$ in comparison with CT4 $(88.92 \pm 1.63 \mathrm{mg} / \mathrm{g})$. In the SPR and ARG groups the concentrations of both metabolic and contractile proteins were not increased compared to the CT7 group. However, after three weeks of spironolactone treatment, the concentration of both metabolic and contractile proteins remained increased $(\mathrm{P}<0.05)$ in comparison with CT7 group (Fig. 3).

Collagenous proteins in both soluble and insoluble fractions were increased in LN4 group $(52.08 \pm 2.02$ and $18.26 \pm 1.80 \mathrm{mg} / \mathrm{g}$, respectively) vs. CT4 group $(44.77 \pm 1.15$ and $11.78 \pm 1.09 \mathrm{mg} / \mathrm{g}$, respectively). No significant changes of the concentration of soluble collagenous proteins were detected in any group with $\mathrm{LVH}$ regression. The regression of increased insoluble collagenous protein concentration was achieved in the SPR and ARG groups, while after spironolactone treatment the concentration of insoluble collagenous proteins remained significantly $(\mathrm{P}<0.05)$ elevated vs. CT7 group (Fig. 4, Table 2).

\section{Discussion}

Administration of L-NAME induced hypertension, hypertrophy of the left ventricle, and the increase in concentration of metabolic, contractile and soluble and insoluble collagenous proteins. The relative weight of the left ventricle was reversed to the original level in all the three recovery groups. During spontaneous regression and regression induced by L-arginine the 

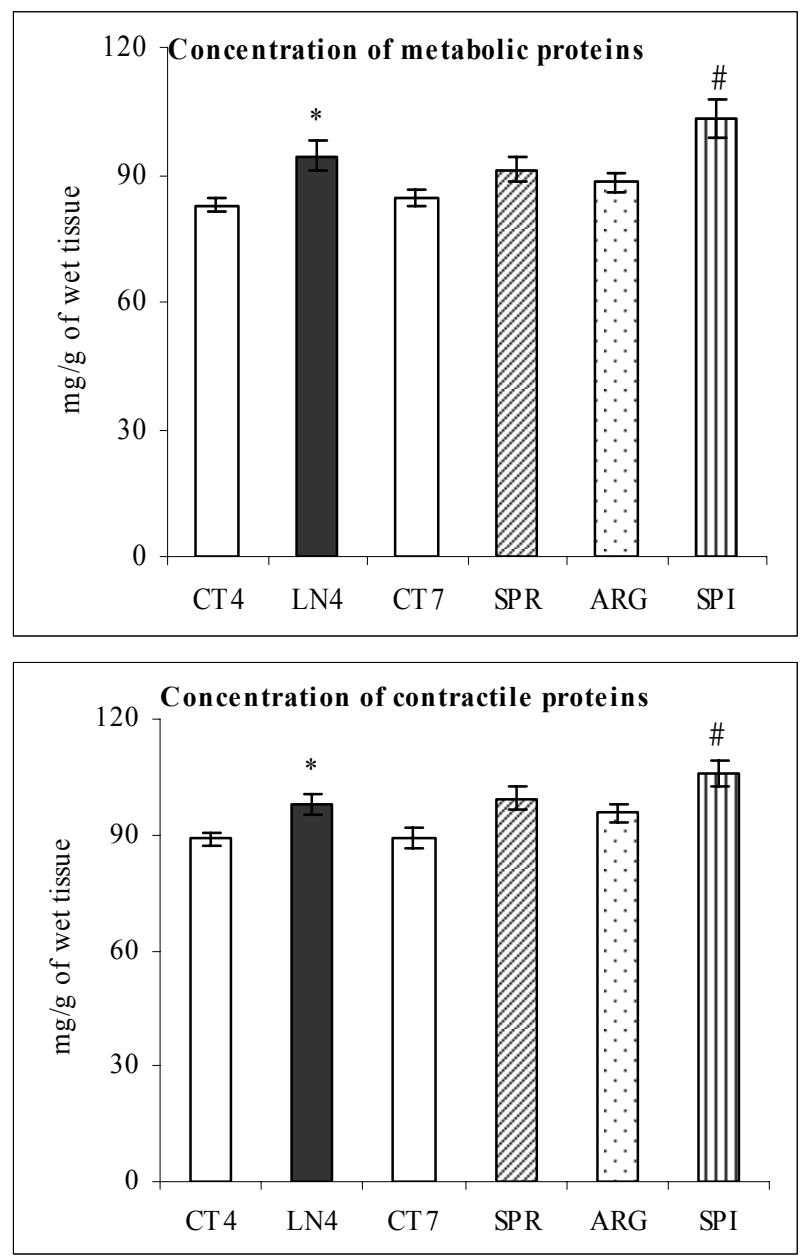

Fig. 3. Concentration ( $\mathrm{mg} / \mathrm{g}$ wet tissue) of metabolic and contractile proteins. CT4 and CT7, controls; LN4, 4-week LNAME; SPR, 4-week L-NAME + 3-week placebo; ARG, 4-week LNAME + 3-week L-arginine; SPI, 4-week L-NAME + 3-week spironolactone.* $\mathrm{P}<0.05$ vs. CT4; ${ }^{~} \mathrm{P}<0.05$ vs. CT7.

concentration of metabolic and contractile proteins as well as of collagenous proteins were not different from the control values. However, after three weeks of spironolactone treatment, the concentration of individual protein fractions remained increased in comparison to the control group.

L-NAME-induced hypertension is associated with the wide range of structural and functional alterations of the heart, kidney and blood vessels (Bernátová et al. 1999, Hropot et al. 1994, Kristek et al. 2005, Okruhlicová et al. 2005, Pereira et al. 2004), however, the underlying mechanisms are not quite clear. NO-deficiency and excessive activation of the reninangiotensin II-aldosterone system seems to play the most important role (Šimko and Šimko 2000). In our previous studies, we tested several substances with respect to their potential protective effect on NO-deficient hypertension.
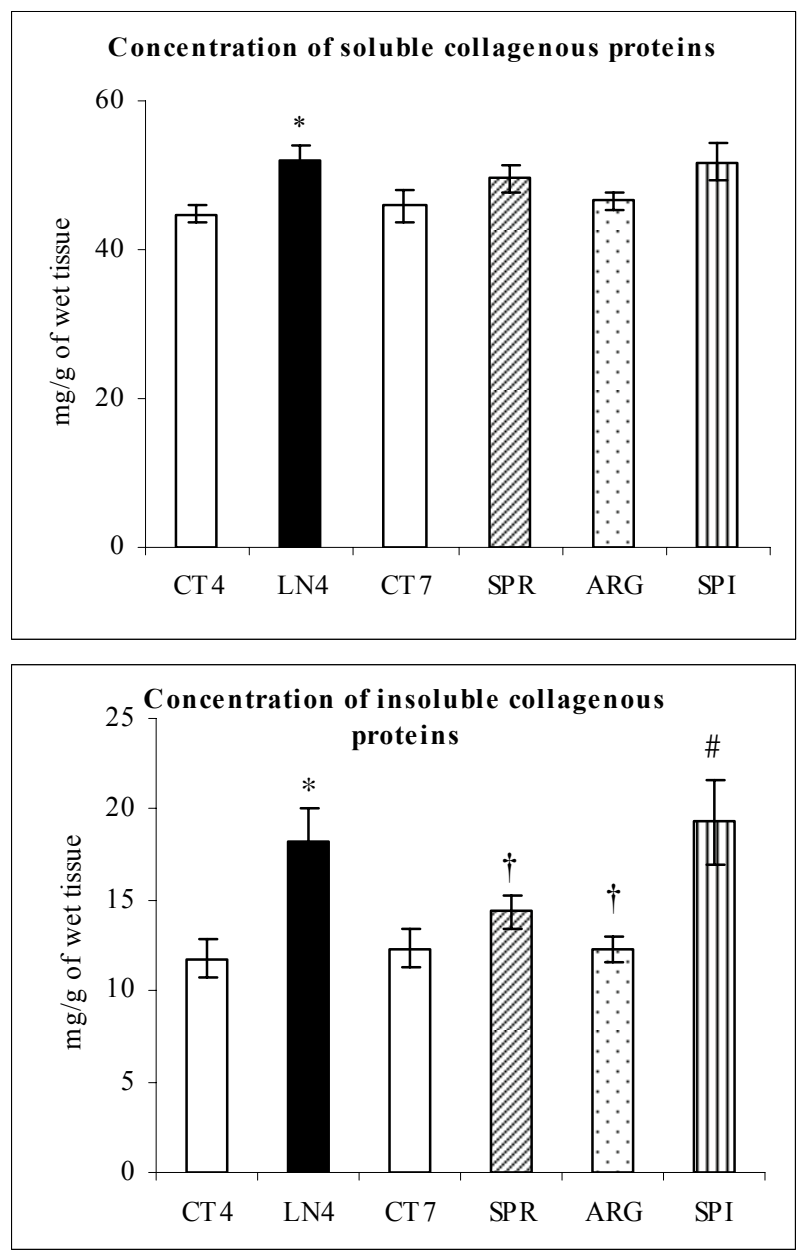

Fig. 4. Concentration ( $\mathrm{mg} / \mathrm{g}$ wet tissue) of soluble and insoluble collagenous proteins. CT4 and CT7, controls; LN4, 4-week L-NAME; SPR, 4-week L-NAME + 3-week placebo; ARG, 4-week L-NAME + 3-week L-arginine; SPI, 4-week L-NAME + 3-week spironolactone. * $\mathrm{P}<0.05$ vs. $\mathrm{CT} 4 ;{ }^{*} \mathrm{P}<0.05$ vs. $\mathrm{CT7} ;{ }^{+} \mathrm{P}<0.05$ vs. LN4.

Captopril prevented both hypertension and LV remodeling (Pecháňová et al. 1997), and spironolactone in a preventive experiment reduced hypertension, LV mass and DNA concentration (Šimko et al. 2007). On the other hand, simvastatin, despite reduction of blood pressure, did not prevent either hypertrophy or fibrosis of the LV and hypertrophy of the aorta (Šimko et al. 2004). L-arginine had no effect on blood pressure and LV remodeling in L-NAME hypertension (Šimko et al. 2005).

There are only seldom data describing the regression of already developed changes induced by chronic L-NAME treatment. In the present study, the growth of myocardium was associated with the enhancement of pepsin-soluble (i.e. newly synthesized collagen) and pepsin-insoluble (i.e. collagen aggregates) collagenous protein concentration. The simultaneous 
increase in metabolic and contractile non-collagenous proteins after long-term L-NAME treatment may represent a potential adaptive response of the myocardium to increased hemodynamic demands. The cessation of L-NAME administration, followed by placebo, L-arginine or spironolactone treatment, resulted in the regression of hypertension and LVH in a threeweek period, while the LV mass was most prominently reduced with spironolactone. The concentration of contractile, metabolic, and collagenous proteins were not significantly different from the control level in SPR and ARG groups, while, surprisingly, in the SPI group all these parameters remained elevated. The discrepancy between LV weight reduction and maintenance of increased non-collagenous and collagenous protein concentration on the level of L-NAME group after spironolactone treatment suggests that spironolactone may have affected myocardial water content in the left ventricle. It has been previously shown that prolonged arterial hypertension may not only be associated with fibrosis but also with an increase in interstitial fluid volume, namely two factors which cause deterioration of cardiac function (Laine and Allen 1991). Indeed, LNAME-induced LVH was shown to be associated with extracellular microedema and mitochondrial edema probably as a result of increased capillary permeability (Tribulová et al. 2000). In our previous work spontaneous regression of $\mathrm{LVH}$ resulted in the decrease of noncollagenous and collagenous protein concentration in the LV, but ACE-inhibitor captopril (similarly as spironolactone in this experiment) maintained the enhanced level of all investigated proteins or even increased it, despite the complete regression of the LVH
(Bernátová et al. 2000). This finding may be related to the fact that ACE-inhibitors have diuretic effect as a consequence of their effect on tubular and glomerular functions (Romero et al. 1988). Analogically, also aldosterone receptors blockers have also diuretic and natriuretic properties by antagonizing the aldosterone effect at the level of renal distal tubules (Lijnen and Petrov 2000). We speculate that regression of LVH in the early phase of spironolactone-induced recovery is associated mainly with a significant reduction of the fluid volume in the myocardial tissue. It would probably need a longer time until spironolactone treatment would also result in the reduction of the concentration of noncollagenous and collagenous proteins.

In conclusion, spontaneous- and L-arginineinduced regression of hypertension resulted in regression of LVH and of protein remodeling of the LV. Spironolactone, however, despite normalization of the LV mass did not reverse contractile, metabolic and collagenous protein remodeling of the LV. We suggest that the early phase of spironolactone-induced recovery is associated with a significant reduction in myocardial fluid volume. Prolongation of spironolactone treatment could also result in the reduction of the non-collagenous and collagenous protein fraction concentration.

\section{Acknowledgements}

This work was partially supported by the Research Project MSM0021620820 and the VEGA grants No. $1 / 3429 / 06$ and 2/6148/26 and APVT grant No. 51027404. Spironolactone was a kind gift of Gedeon Richter, Ltd, Budapest.

\section{References}

BASS A, ŠAMÁNEK M, OŠŤÁDAL B, HUČÍN B, STEJSKALOVÁ M, PELOUCH V: Differences between atrial and ventricular energy supplying enzymes in children. J Appl Cardiol 3: 397-405, 1988.

BERNÁTOVÁ I, PECHÁŇOVÁ O, ŠIMKO F: Effect of captopril in L-NAME-induced hypertension on the rat myocardium, aorta, brain and kidney. Exp Physiol 84: 1095-1105, 1999.

BERNÁTOVÁ I, PECHÁŇOVÁ O, PELOUCH V, ŠIMKO F: Regression of chronic L-NAME-treatment-induced left ventricular hypertrophy: effect of captopril. J Mol Cell Cardiol 32: 177-185, 2000.

BRILLA CG, MATSUBARA LS, WEBER KT: Anti-aldosterone treatment and the prevention of myocardial fibrosis in primary and secondary hyperaldosteronism. J Mol Cell Cardiol 25: 563-575, 1993.

DEVEREUX RB, WACHTELL K, GERDTS E, BOMAN K, NIEMINEN MS, PAPADEMETRIOU V, ROKKEDAL J, HARRIS K, AURUP P, DAHLÖF B: Prognostic significance of left ventricular mass change during treatment of hypertension. JAMA 292: 2350-2356, 2004. 
HROPOT M, GROTSCH H, KLAUS E, LANGER KH, LINZ W, WIEMER G, SCHÖLKENS BA: Ramipril prevents the detrimental sequels of chronic NO synthase inhibition in rats: hypertension, cardiac hypertrophy and renal insufficiency. Naunyn-Schmiedeberg Arch Pharmacol 350: 646-652, 1994.

KLINGBEIL AU, SCHNEIDER M, MARTUS P, MESSERLI FH, SCHMIEDER RE: A meta-analysis of the effects of treatment on left venricular mass in essential hypertension. Am J Med 115: 41-46, 2003.

KOJŠOVÁ S, JENDEKOVÁ L, ZICHA J, KUNEŠ, J, ANDRIANTSITOHAJNA R, PECHÁŇOVÁ O: The effect of different antioxidants on nitric oxide production in hypertensive rats. Physiol Res 55 (Suppl 1): S13-S16, 2006.

KOLPAKOV V, GORDON D, KULIK TJ: Nitric-oxide generating compounds inhibit total protein and collagen synthesis in cultured vascular smooth muscle cells. Circ Res 76: 305-309, 1995.

KRISTEK F, KOPRDOVÁ R, CEBOVÁ M, TÖRÖK J: Different effect of NO-donnors on geometry and reactivity of conduit arteries in SHR and NO-deficient rats. Physiol Res 54: 55P, 2005.

LAINE GA, ALLEN SJ: Left ventricular myocardial edema. Lymph flow, interstitial fibrosis, and cardiac edema. Circ Res 68: 1713-1721, 1991.

LIJNEN P, PETROV V: Induction of cardiac fibrosis by aldosterone. J Moll Cell Cardiol 32: 865-879, 2000.

LOWRY OH, ROSENBROUGH NJ, FARR AL, RANDALL RJ: Protein measurement with Folin phenol reagent. J Biol Chem 193: 265-272, 1951.

MANDARIM-DE-LACERDA CA, PEREIRA LM: The effects of spironolactone monotherapy on blood pressure and myocardial remodeling in spontaneously hypertensive rats: a stereological study. J Biomed Sci 10, 50-57, 2003.

MATSUOKA H, NAKATA M, KOHNO K, KOGA Y, NOMURA G, TOSHIMA H, IMAIZUMI T: Chronic l-arginine administration attenuates cardiac hypertrophy in spontaneously hypertensive rats. Hypertension 27: 14-18, 1996.

NAKAKI T, HISHIKAWA K, SUZUKI H, SARUTA T, KATO R: L-arginine-induced hypotension. Lancet 336: 696, 1990.

OKRUHLICOVÁ K, DLUGOŠOVÁ M, FIALOVÁ N, TRIBULOVÁ I, BERNÁTOVÁ I, PECHÁŇOVÁ O: Capillary histochemical and subcellular alterations in the heart of NO-deficient rats. Physiol Res 54: 56P, 2005.

PECHÁŇOVÁ O, BERNÁTOVÁ I, PELOUCH V, ŠIMKO F: Protein remodeling of the heart in NO-deficient hypertension: the effect of captopril. J Mol Cell Cardiol 29: 3365-3374, 1997.

PELOUCH V, MILEROVÁ M, OŠŤÁDAL B, ŠAMÁNEK M, HUČÍN B: Protein profiling of human atrial and ventricular musculature: the effect of normoxaemia and hypoxaemia in congenital heart diseases. Physiol Res 42: 235-242, 1993.

PELOUCH V, MILEROVÁ M, OŠŤÁDAL B, HUČÍN B, ŠAMÁNEK M: Differences between atrial and ventricular protein profiling in children with congenital heart disease. Mol Cell Biochem 147: 43-49, 1995.

PELOUCH V, KOLÁŘ F, KHUCHUA ZA, ELIZAROVÁ GV, MILEROVÁ M, OŠŤÁDAL B, SAKA VA: Cardiac phosphocreatine deficiency induced by GPA during postnatal development in rat. Mol Cell Biochem 163/164: 67-76, 1996.

PEREIRA LM, BEZERRA DG, MANDARIM-DE-LACERDA CA: Aortic wall remodeling in rats with nitric oxide deficiency treated by enalapril or verapamil. Pathol Res Pract 200: 211-217, 2004.

PITT B, ZANNAD D F, REMME WJ, CODY R, CASTAIGNE A, PEREZ A, PALENSKY J, WITTES J, for the Randomized Aldactone Evaluation Study Investigators: the effect of spironolactone on morbidity and mortality in patients with severe heart failure. N Engl J Med 341: 709-717, 1999.

ROMERO JC, RUILOPE LM, BENTLEY MD, FIKSEN-OLSEN MJ, LAHERA V, VIDAL MJ: Comparison of the effects of calcium antagonists and converting enzyme inhibitors on renal function under normal and hypertensive conditions. Am J Cardiol 62: 59G-68G, 1988.

ŠIMKO F: Statins - a perspective for left ventricular hypertrophy treatment. Eur J Clin Invest 37: 681-691, 2007a.

ŠIMKO F: Is NO the king? Pathophysiological benefit with uncertain clinical impact. Physiol Res 56 (Suppl 2): S1-S6, 2007b.

ŠIMKO F, PAULIS L: Melatonin as a potential antihypertensive treatment. J Pineal Res 42: 319-322, 2007. 
ŠIMKO F, ŠIMKO J: The potential role of nitric oxide in the hypertrophic growth of the left ventricle. Physiol Res 49: 37-46, 2000.

ŠIMKO F, BADA V, ŠIMKOVÁ M, ŠIMKO J, KOVÁCS L, HULÍN I: The significance of aldosterone in chronic heart failure: the RALES study. Vnitř lék 48: 767-772, 2002.

ŠIMKO F, MATÚŠKOVÁ J, LUPTÁK I, KRAJČÍROVIČOVÁ K, KUCHARSKÁ J, GVOZDJÁKOVÁ A, BABÁL P, PECHÁŇOVÁ O: Effect of simvastatin on remodeling of the left ventricle and aorta in L-NAME-induced hypertension. Life Sci 74: 1211-1224, 2004.

ŠIMKO F, LUPTÁK I, MATÚŠKOVÁ J, KRAJČÍROVIČOVÁ K, SUMBALOVÁ Z, KUCHARSKÁ J, GVOZDJÁKOVÁ A, ŠIMKO J, BABÁL P, PECHÁŇOVÁ O, BERNÁTOVÁ I: L-arginine fails to protect against myocardial remodeling in L-NAME-induced hypertension. Eur J Clin Invest 35: 362-368, 2005.

ŠIMKO F, MATÚŠKOVÁ J, LUPTÁK I, KRAJČíROVIČOVÁ K, ŠTVRTINA S, POMŠÁR J, PELOUCH V, PAULIS L', PECHÁŇOVÁ O: Spironolactone differently influences remodeling of the left ventricle and aorta in L-NAME-induced hypertension. Physiol Res 56 (Suppl 2): S25-S32, 2007.

TRIBULOVÁ N, OKRUHLICOVÁ L, BERNÁTOVÁ I, PECHÁŇOVÁ O: Chronic disturbance in nitric oxide production results in histochemical and subcellular alterations of the rat heart. Physiol Res 49: 77-88, 2000.

ZANNAD F, ALLA F, DOUSSET B, PEREZ A, PITT B: Limitation of excessive extracellular matrix turnover may contribute to survival benefit of spironolactone therapy in patients with congestive heart failure: insights from the randomized aldactone evalution study (RALES). RALES Investigators. Circulation 102: 2700-2706, 2000.

\section{Corresponding author}

F. Šimko, Department of Pathophysiology, School of Medicine, Comenius University, Sasinkova 4, 81372 Bratislava, Slovak Republic. Fax: +421-2-59357601. E-mail: fedor.simko@fmed.uniba.sk 